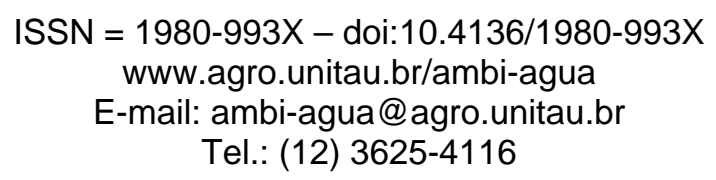

\title{
Classificação da precipitação anual e da quadra chuvosa da bacia do rio Paraíba utilizando índice de Anomalia de Chuva (IAC)
}

(doi:10.4136/ambi-agua.105)

\author{
Lincoln Eloi de Araújoㅜㄹ João Miguel de Moraes Neto $^{2}$; Francisco de Assis Salviano de \\ Sousa $^{1}$ \\ ${ }^{1}$ UACA - Unidade Acadêmica de Ciências Atmosféricas - UFCG \\ E-mail: lincolneloi@yahoo.com.br; fassis@dca.ufcg.edu.br \\ ${ }^{2}$ UAEAg - Unidade Acadêmica de Engenharia Agrícola - UFCG \\ E-mail: moraes@deag.ufcg.edu.br
}

\section{RESUMO}

A bacia hidrográfica do rio Paraíba é de extrema importância para o setor agrícola e, consequentemente, para a socioeconomia local e regional. Este trabalho tem como objetivo principal analisar a climatologia da bacia do rio Paraíba, incluindo a análise de como a variabilidade climática influencia a precipitação local e de como variam espaçotemporalmente as chuvas na região, utilizando a ferramenta IAC desenvolvido por Rooy (1965). Foi encontrada semelhança entre o padrão de precipitação da região do Taperoá e Alto Paraíba e das sub-bacias do Médio e Baixo Paraíba. Umm "ponto de inflexão" na distribuição de precipitação foi encontrado na região do Taperoá e Alto Paraíba, na qual, até a década de 1960, foram observados anos secos consecutivos. Já para as sub-bacias do Médio e Baixo Paraíba, foi verificada semelhança na alternância entre anos secos e chuvosos ao longo da série de IAC.

Palavras-chave: variabilidade; regionalização; IAC.

\section{Classification of annual rainfall and the rainy quarter of the year in the Paraíba river basin using Rain Anomaly Index (RAI)}

\begin{abstract}
The Paraíba river basin is very important to the agricultural sector and to the local and regional socio-economy. This study aims at investigating the climatology of the Paraíba river basin including the analysis of the climate variability influence on local precipitation and the study of rainfall space-time variability in the region, using a tool IAC developed by Rooy (1965). Similarity was found between the pattern of precipitation in the region of High Paraíba and Taperoá and sub-basins of the Middle and Low Paraíba. A "turning point" in the distribution of precipitation was found in the region of High Paraíba and Taperoá, which until the 1960s consecutively dry years were observed. In the other hand, similarity in the alternation between dry and wet years was verified over the IAC series for the sub-basins of the Middle and Low Paraíba.
\end{abstract}

Keywords: Variability; regionalization; RAI.

\section{INTRODUÇÃO}

O monitoramento de períodos secos ou chuvosos e da variabilidade espaço-temporal da precipitação no Nordeste brasileiro são de extrema importância devido a aspectos como: a existência de inúmeros projetos de irrigação implantados e a serem implantados ao longo dos 
principais rios; o abastecimento de água das grandes cidades é, em sua maioria, dependente direto do escoamento dos rios, ou indiretamente do volume acumulado nas barragens; a maioria das culturas agrícolas depende exclusivamente da regularidade das chuvas e a possibilidade de uso de água subterrânea é pequena quando comparada ao da água superficial (Freitas, 2004 e 2005).

A precipitação pluviométrica no Nordeste brasileiro é resultante do acoplamento de vários sistemas atmosféricos de várias escalas quase periódicos, como a Zona de Convergência Intertropical (Uvo, 1989), os Vórtices Ciclônicos de Ar Superior (Kousky e Gan, 1981), os Sistemas Frontais (Kousky, 1979), e os Distúrbios de Leste (Espinoza, 1996), que podem ser modificados pelas características fisiográficas da região e por anomalias atmosféricas de escala planetária. O dipolo do Atlântico e o ENSO, que modificam a frequência, distribuição espacial e intensidade desses sistemas, afeta diretamente a agricultura e os recursos hídricos.

Com base nessa precipitação irregular, faz-se necessário o monitoramento por meio do emprego de índices climáticos. Com base neles, pode-se desenvolver um sistema de acompanhamento das características dos períodos secos ou chuvosos, com informações anuais, sazonais ou mensais, com as quais se pode conhecer profundamente a climatologia de uma região, e verificar os impactos que o clima global causa sobre a distribuição pluviométrica local, ou seja, a regionalização da precipitação para determinado local (Da Silva, 2009).

Entretanto, é pouco conhecido que a Paraíba é o Estado do Nordeste que apresenta uma das maiores variabilidades espaciais nas chuvas, vez que o agreste/litoral apresenta precipitações médias anuais acima de 1083,4 mm/ano, seguido do sertão, com valores médios de 821,9 mm/ano e, por fim, a região do Cariri/Curimataú com média alcançando até 516,1 $\mathrm{mm} / \mathrm{ano}$ (Araújo et al., 2003).

Com características semelhantes as do Estado da Paraíba, a bacia do rio Paraíba possui área de 20.000,00 km², evidenciando dois regimes de precipitação distintos ao longo de toda a bacia, um de fevereiro a maio (região do Taperoá e Alto Paraíba) e o outro de abril a julho (Médio Paraíba e Baixo Paraíba), conforme Araújo (2006).

Assim, com todas essas abordagens, este trabalho tem como objetivo principal analisar a climatologia da bacia do rio Paraíba, como a variabilidade climática influencia a precipitação local e como se dá a variabilidade espaço-temporal das chuvas na região, utilizando para isso a ferramenta Índice de Anomalia de Chuva (IAC).

\section{2. ÍNDICE DE ANOMALIA DE CHUVA (IAC)}

De acordo com Freitas (2004 e 2005), no Nordeste brasileiro, a previsão e o monitoramento de períodos secos ou períodos chuvosos são particularmente úteis devido aos seguintes aspectos:

(1) a existência de inúmeros projetos de irrigação implantados e a serem implantados ao longo dos principais rios;

(2) o abastecimento de água das grandes cidades é, em sua maioria, dependente direto do escoamento dos rios, ou indiretamente do volume acumulado nas barragens;

(3) a maioria das culturas agrícolas depende exclusivamente da regularidade das chuvas e;

(4) a possibilidade de uso de água subterrânea é pequena quando comparada ao da água superficial.

Desse modo, o monitoramento desses períodos pode ser efetuado pelo emprego de índices. Com base neles, pode-se desenvolver um sistema de acompanhamento das 
características dos períodos extremos (secos ou chuvosos), assim como as diferenciadas medidas a serem efetivadas de acordo com os valores atingidos por tais parâmetros.

Um ponto crucial no emprego de um índice como esse, bem como de qualquer outro, reside na escolha do patamar a ser estabelecido para a definição de um período de seca. Esse patamar é, de modo geral, escolhido arbitrariamente.

Segundo Da Silva (2009), a escolha do patamar para a separação entre anos secos e úmidos não deve ser, portanto, arbitrária, mas deve ser escolhido com base no conhecimento climático da região, na análise das características dos períodos históricos de secas e das correspondentes consequências à população e ao meio ambiente atingidos. Esses efeitos dependem, por sua vez, da infraestrutura hídrica existente, isto é, variam com o tempo.

Freitas (2004 e 2005) utilizou o índice IAC para localidades no Estado do Ceará e observou que, com base nele, é possível fazer uma comparação das condições atuais de precipitação em relação aos valores históricos, servindo ainda para avaliar a distribuição espacial do evento, consoante sua intensidade.

Mauget (2005), ao estudar a variação multidecadal da precipitação de 1901 a 1998, para identificar as concentrações mais significativas de anos úmidos e secos dentro da série, em regiões continentais, encontrou alta incidência de anos úmidos na América do Norte de 1972 a 1998, com oito dos dez anos mais úmidos desde 1901, ou seja, oito eventos aconteceram durante esse último período de 27 anos.

Para a região norte da Europa, foram encontrados sete dos dez anos mais úmidos de 1978 a 1998. Regimes secos e úmidos significantes foram encontrados nas últimas décadas do século XX. O autor sugere que esses períodos úmidos mais recentes sejam realmente efeito de causas terrestres, tendo evidência mais notável numa larga mudança do padrão do clima do Atlântico Norte.

Gonçalves et al. (2006) determinaram o índice IAC para 15 estações situadas no rio São Francisco, fato que mostrou que a incidência de anos secos é substancialmente maior na região estudada. Pela aplicação do índice em áreas situadas à jusante da hidrelétrica de Sobradinho, pode-se explicar a ocorrência de cheias e inundações ocorridas no sertão pernambucano.

Da Silva et al. (2007), ao utilizarem o IAC para verificar a variabilidade das chuvas na bacia do rio Mundaú (AL e PE), encontraram uma modificação no padrão de distribuição de precipitação. Antes de 1974, nas sub-bacias do Médio Mundaú e Alto Mundaú, os anos foram mais secos e, após 1974, foram mais úmidos, ocorrendo o contrário no Baixo Mundaú.

\section{MATERIAL E MÉTODOS}

Os dados de precipitação pluviométrica utilizados na pesquisa foram obtidos da série histórica da SUDENE e complementos da UACA (Unidade Acadêmica de Ciências Atmosféricas - UFCG) de 1910 a 2004 (65 municípios).

A área de estudo deste trabalho é a bacia hidrográfica do rio Paraíba (Figura 1), que se localiza no semiárido paraibano e integra as mesorregiões da Borborema, do Agreste e do Litoral, abrangendo uma área de $20.127,17 \mathrm{~km}^{2}$, compreendida entre as latitudes $6^{\circ} 51^{\prime} 31^{\text {'' e }}$

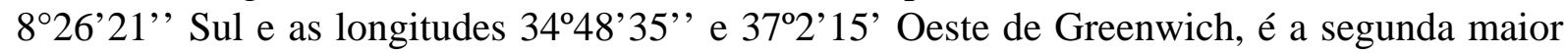
do Estado da Paraíba, pois abrange 38\% do seu território, abastecendo 84 municípios, abrigando 1.885.655 habitantes que correspondem a 52\% da sua população total. 


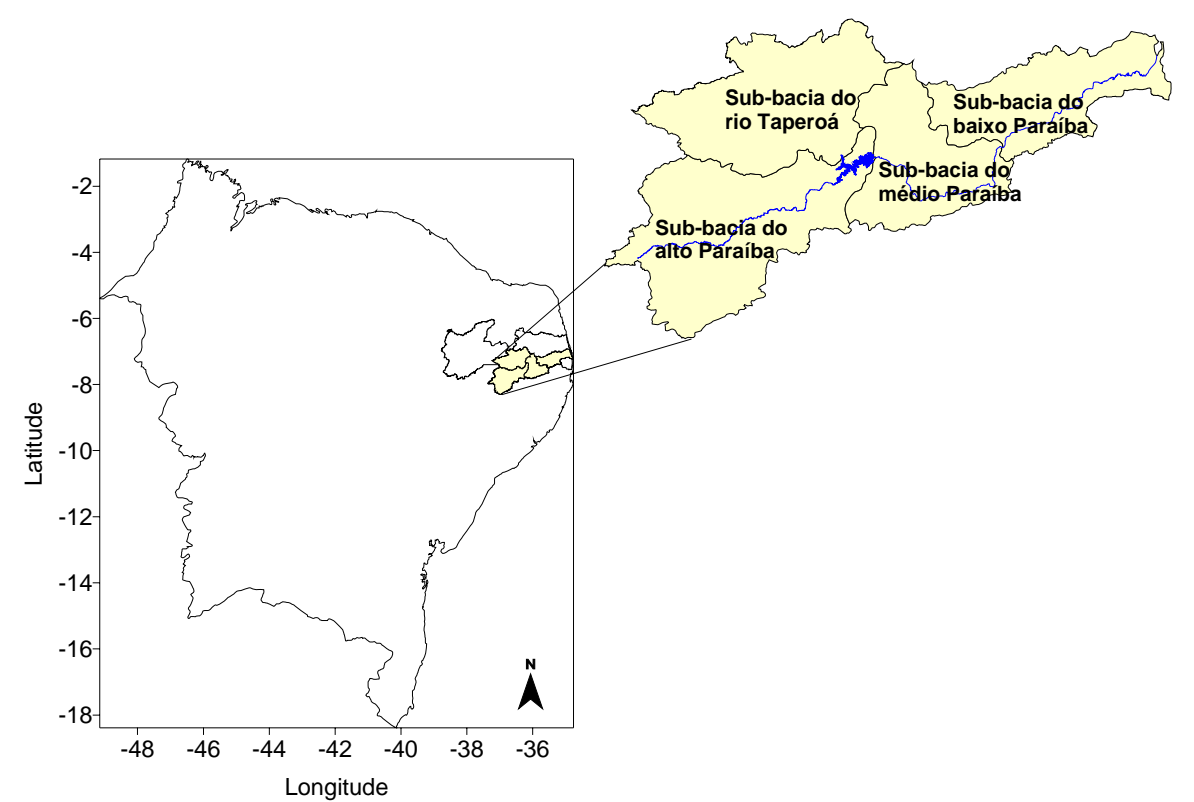

Figura 1. Localização da bacia do rio Paraíba.

A bacia apresenta intensa variabilidade climática, características físicas e uma grande extensão geográfica, e está dividida em quatro sub-regiões, são elas: Alto, Médio e Baixo Curso do rio Paraíba e a região do curso do rio Taperoá.

As séries de precipitação mensal serão utilizadas para avaliar o comportamento sazonal da chuva e detectar períodos considerados "excessivamente” úmidos ou secos.

A avaliação do grau de severidade e duração dos períodos secos e úmidos será feita por meio do cálculo do índice IAC, (Freitas, 2004 e 2005), obtido a partir das equações:

$I A C=3\left[\frac{(N-\bar{N})}{(\bar{M}-\bar{N})}\right]$, para anomalias positivas

$I A C=-3\left[\frac{(N-\bar{N})}{(\bar{X}-\bar{N})}\right]$, para anomalias negativas

em que:

$\mathrm{N}$ = precipitação mensal atual (mm);

$\overline{\mathrm{N}}=$ precipitação média mensal da série histórica (mm);

$\overline{\mathrm{M}}=$ média das dez maiores precipitações mensais da série histórica (mm); e,

$\overline{\mathrm{X}}=$ média das dez menores precipitações mensais da série histórica (mm).

A partir da metodologia de Freitas (2004 e 2005), foi adaptada uma nova classificação de anos secos e úmidos (Tabela 1).

Tabela 1. Classes de Intensidade do Índice de Anomalia de Chuva da bacia do rio Paraíba.

\begin{tabular}{c|cc}
\hline \multirow{4}{*}{ Índice de Anomalia de } & Faixa do IAC & Classe de Intensidade \\
\cline { 2 - 3 } Chuva (IAC) & De 4 acima & Extremamente Úmido \\
& 2 a 4 & Muito Úmido \\
& 0 a 2 & Úmido \\
& 0 a -2 & Seco \\
& -2 a -4 & Muito Seco \\
& De -4 abaixo & Extremamente Seco \\
\hline
\end{tabular}




\section{RESULTADOS E DISCUSSÃO}

\section{1. Índice de Anomalia de Chuva (IAC)}

Na Figura 2, observam-se valores positivos de IAC em toda bacia do rio Paraíba, com 44 anos chuvosos, variando entre as classes de chuvoso, muito chuvoso ou extremamente chuvoso. Similarmente aos valores positivos de IAC, os valores negativos representam os anos secos, com 46 anos negativos, cuja classificação sugere ano seco, muito seco ou extremamente seco.

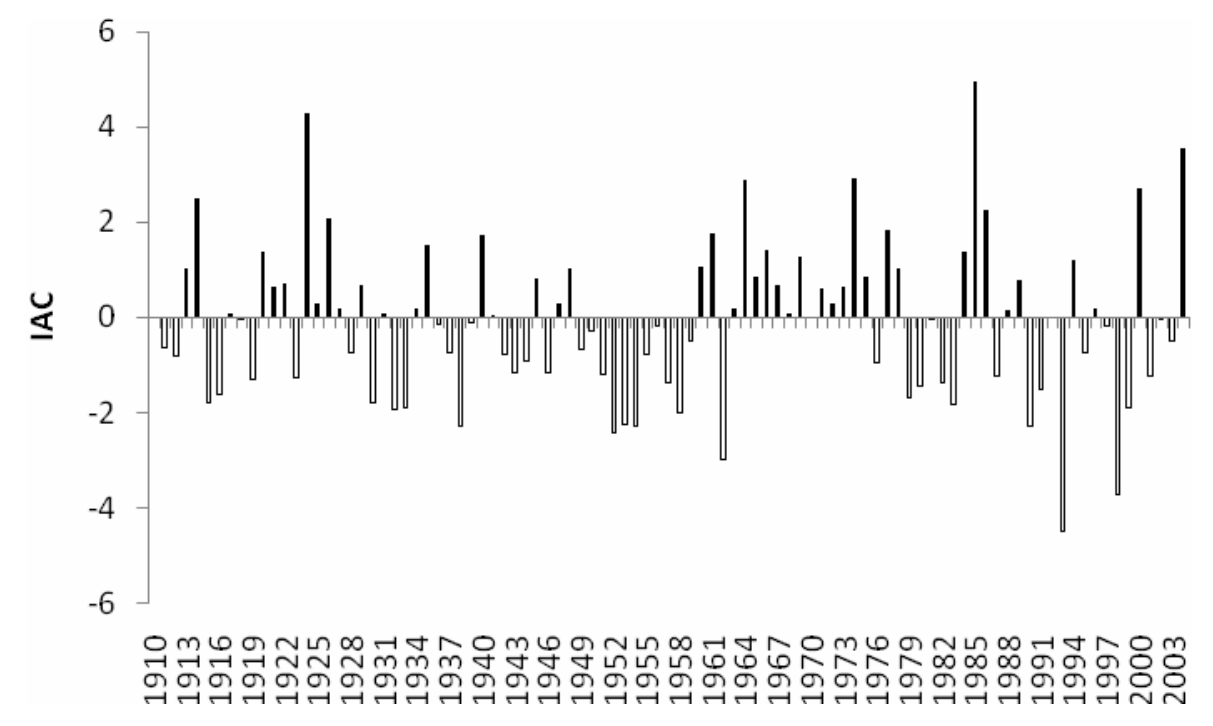

Figura 2. Índice de Anomalia de Chuva da bacia do rio Paraíba.

O índice de Anomalia de Chuva (IAC) da bacia do rio Paraíba tem algumas peculiaridades no decorrer do tempo, pois até a década de 50 os valores positivos eram em maior número, mas com alternância com os valores negativos. No entanto, do início da década de 50 até o início dos anos 60, ocorre uma modificação na variação da precipitação da bacia do rio Paraíba, anos mais secos são mais evidentes, em que ocorre um "ponto de inflexão”, que mostra uma possível variação climática no padrão da precipitação na região.

Após esse período de modificação no padrão da precipitação da região, ocorre o inverso, no inicio da década de 60, valores positivos de IAC tornam-se mais comuns, ou seja, há ocorrência de mais anos úmidos. Logo após essas duas "janelas de variação climática” da precipitação na bacia do rio Paraíba, ou seja, dois períodos distintos, um bem seco e outro bem chuvoso, o padrão da precipitação volta a sua normalidade, com anos secos decorrentes de anos úmidos, ou vice e versa, mas com uma ressalva, os anos positivos passaram a ocorrer em menor número do que os anos mais secos, diferentemente do observado antes da década de 50, a qual tinha anos úmidos em maior quantidade do que secos. Dessa forma, vale ressaltar que ocorreu uma modificação importante no padrão da precipitação média da bacia do rio Paraíba, ocorrendo mais períodos de anos secos do que chuvosos.

Como visto anteriormente, a espacialização da precipitação na bacia do rio Paraíba é bem diferenciada quando analisada individualmente, ou seja, como um todo, necessita-se analisar com maior rigor a área de estudo. Tendo em vista essa característica, decidiu-se avaliar tal variabilidade temporal climatológica de cada sub-bacia da bacia do rio Paraíba.

A espacialização temporal da precipitação na sub-bacia do rio Taperoá (Figura 3) mostra que, a média da região é de, aproximadamente, $30 \mathrm{~mm}$ e que o período chuvoso tem início no mês de fevereiro e término no mês de maio, quadra mais chuvosa, com valores máximos de precipitação de $90 \mathrm{~mm}$ em média no mês de março. Valores mais amenos encontram-se nos 
meses de setembro a dezembro, o qual se caracteriza como período mais seco do ano, com valores de precipitação abaixo de 10 mm em média para o mês de setembro.

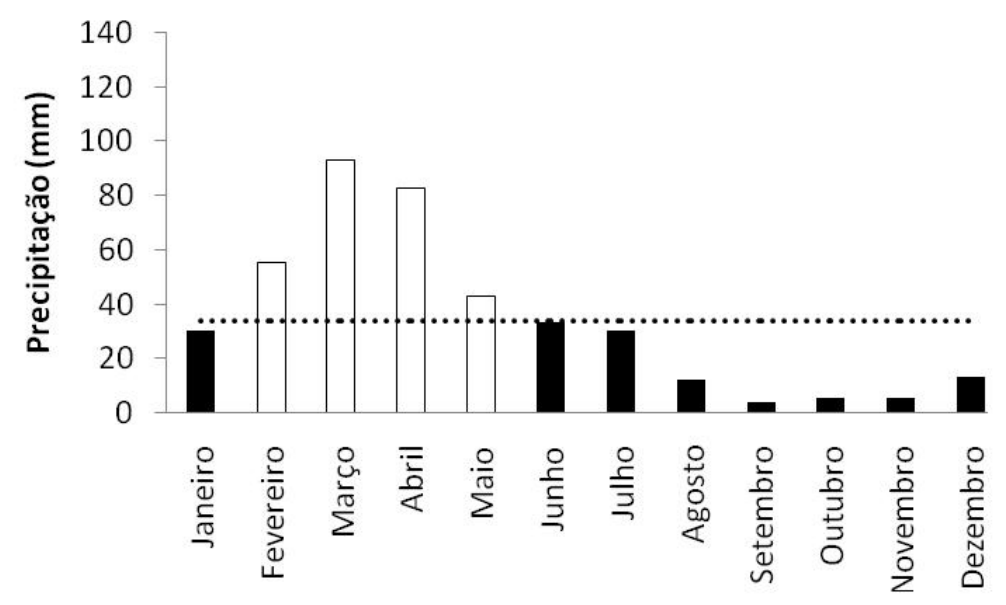

Figura 3. Fluviograma da sub-bacia do Taperoá.

Para melhor avaliar o grau de severidade dos eventos e de duração de períodos secos e úmidos, utilizou-se nesta seção o Índice de Anomalia de Chuva (IAC) para cada sub-bacia da área de estudo, por causa da variabilidade da precipitação de região para região.

A Figura 4 exibe o IAC da sub-bacia do rio Taperoá, que se apresenta semelhante ao índice geral da bacia do rio Paraíba (Figura 3), que em sua maioria mostra alternância entre os valores positivos e negativos, mas com maior predominância de anos secos até o inicio da década de 50. Logo após esse período seco, observa-se também o "ponto de inflexão" citado anteriormente, o qual ocorre nos anos 50, com uma sequência de anos secos em toda área da sub-bacia do rio Taperoá.

Após esse período de modificação da precipitação na sub-bacia do rio Taperoá, ocorre o inverso, na década de 60, os valores positivos de IAC tornam-se mais comuns, destaca-se esse período como chuvoso para toda região. Ao término da década de 70 o padrão volta a sua normalidade, com anos secos e anos úmidos acontecendo no decorrer do tempo alternadamente.

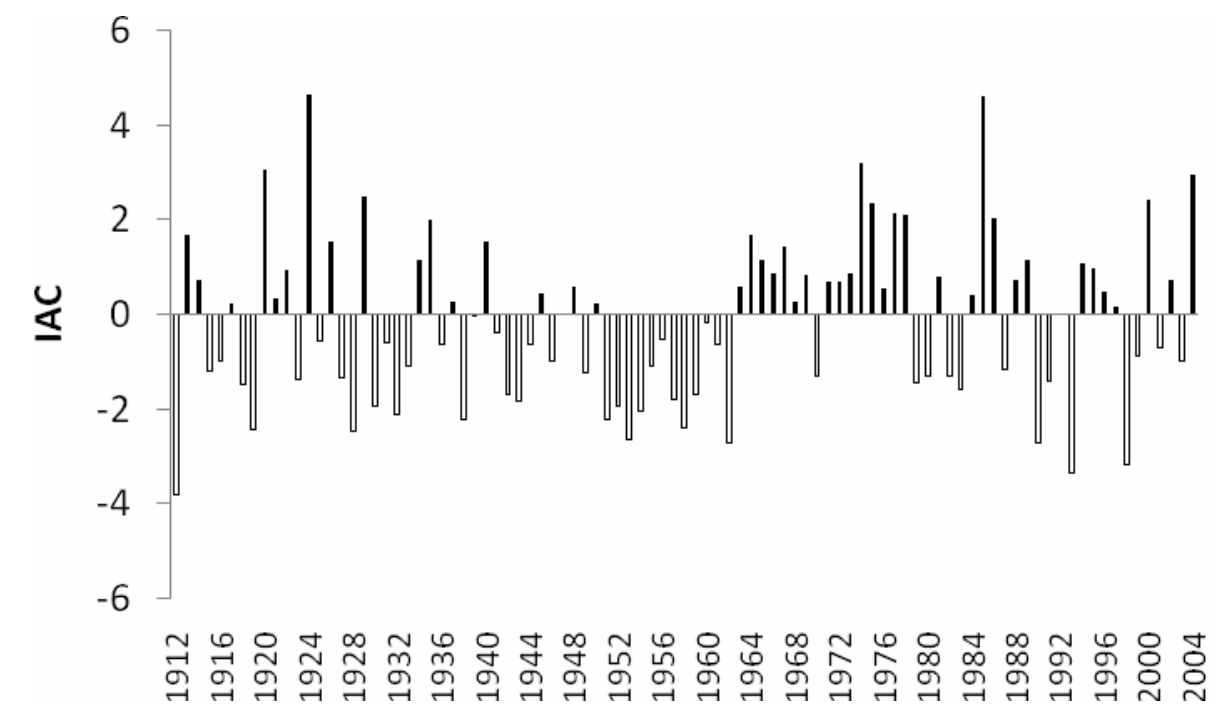

Figura 4. IAC sub-bacia do Taperoá.

Para melhor avaliar a variabilidade temporal da precipitação e observar as diferenças entre as quadras chuvosas na sub-bacia do rio Taperoá, analisaram-se anos específicos 
aleatórios da série de IAC, foram escolhidos dois anos secos (1987 e 1990) e dois anos úmidos (1984 e 2004).

A Figura 5 mostra o IAC da sub-bacia do rio Taperoá para os anos de 1987 e 1990, anos em que o IAC apresentou-se negativo. Ao longo desses anos, apenas um mês apresentou precipitação mensal acima da média (março), destaca-se o inicio da Quadra 1, quando se observa a menor variação entre os dois anos secos, com diferença para os meses de janeiro e março de 1987, que obtiveram valores positivos de IAC.

Esses dois anos secos, de acordo com Da Silva (2009) estão associados à atuação dos Vórtices Ciclônicos de Altos Níveis (VCAN), pela convecção e instabilidade devido ao aquecimento da superfície no verão diferenciados dos demais anos da série e , porque, durante o ano de 1987, ocorreu um El Niño intenso. O total de precipitação na quadra chuvosa desses anos foi $247,8 \mathrm{~mm}$ em 1987 e de $78,7 \mathrm{~mm}$ em 1990, equivalendo a $81,8 \%$ e 47,8\% do total anual, respectivamente.

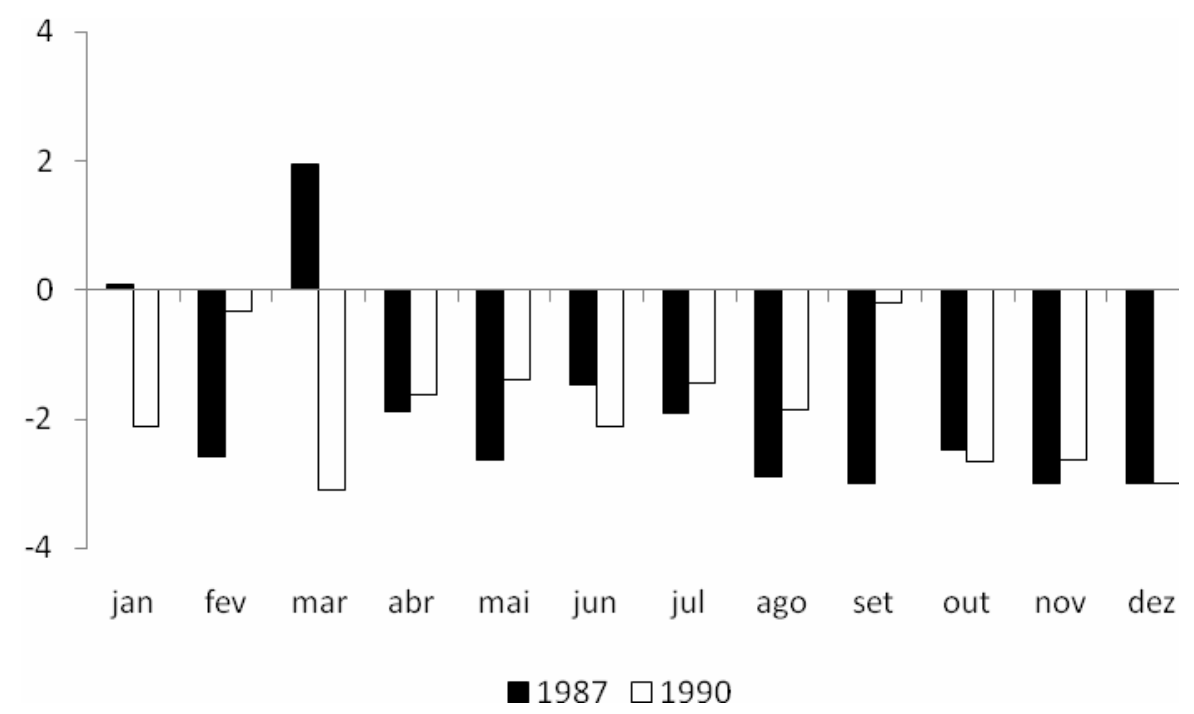

Figura 5. IAC mensais de anos secos da sub-bacia do rio Taperoá.

Na Figura 6 tem-se IAC mensal para os anos de 1984 e 2004, anos em que o IAC anual apresentou-se positivo, ou seja, ano chuvoso. Percebe-se que nesses anos úmidos a contribuição da quadra chuvosa foi muito significativa, principalmente o ano de 2004, o qual foi bastante chuvoso nos meses de janeiro e fevereiro, principalmente nas regiões da subbacia do rio Taperoá e Alto Paraíba, e, para os demais meses, o seu comportamento modificou-se variando de seco para úmido no decorrer do ano.

De acordo com Brito e Braga (2005), as fortes chuvas ocorridas no Estado da Paraíba, foram as mais intensas dos últimos 50 anos e foram produzidas pela interação da Zona de Convergência Intertropical (ZCIT), pelas atividades convectivas oriundas do Vórtice Ciclônico de Altos Níveis (VCANS) e pela Zona de Convergência do Atlântico Sul (ZCAS). E 1984 foi considerado um ano chuvoso por causa da atuação de uma La Niña fraca que durou todo o ano (CPTEC), favorecendo a precipitação na Quadra 2.

A quadra chuvosa nos anos de 1984 e 2004 contribuiu com 358,8 mm e 162,7 mm, respectivamente, o que equivale a $79,8 \%$ do total anual do primeiro ano e $22 \%$ do total anual do segundo ano citado anteriormente. 


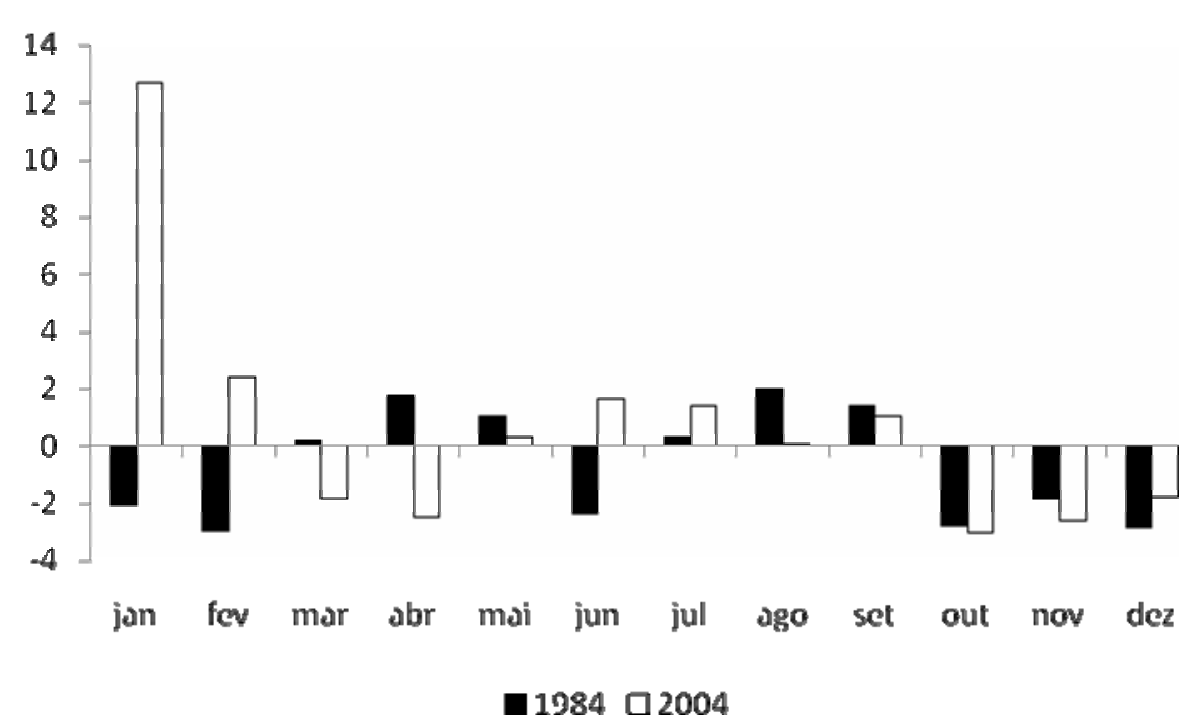

Figura 6. IAC mensais de anos úmidos da sub-bacia do rio Taperoá.

Continuando a analise da espacialização temporal da precipitação, evidencia-se neste momento a sub-bacia do Alto Paraíba que se caracteriza semelhantemente com a sub-bacia do rio Taperoá, uma peculiaridade de diferença entre elas são os valores totais mensais da região do alto Paraíba que são mais elevados do que a outra região.

A Figura 7 mostra a variação da precipitação mensal do Alto Paraíba, com quadra chuvosa nos meses de fevereiro a maio, com média de, aproximadamente, $40 \mathrm{~mm}$ e com valores máximos de precipitação, dentro da quadra chuvosa, acima de $114 \mathrm{~mm}$ em média, no mês de março, o qual é mais eficiente em termos de precipitação por causa da atuação da Zona de Convergência Intertropical (ZCIT) que atinge seu máximo no mês de março. Ressalta-se que esse mês, devido à intensa precipitação, é o mês mais importante para o aporte hídrico dos mananciais nas regiões da sub-bacia do rio Taperoá e Alto Paraíba.

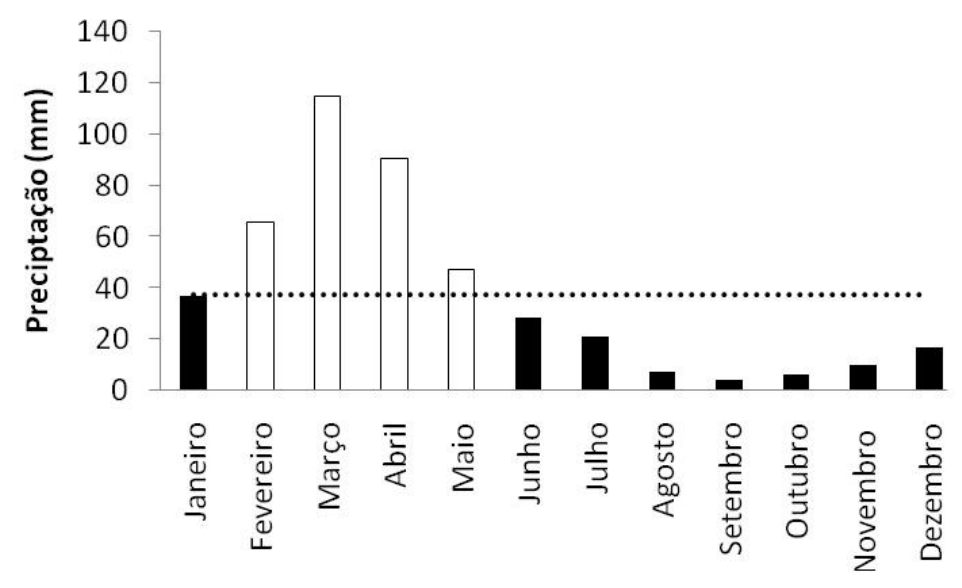

Figura 7. Fluviograma da sub-bacia do Alto Paraíba.

Os menores valores de precipitação são encontrados nos meses de agosto a novembro, o qual se caracteriza como período mais seco do ano, com valores de precipitação abaixo de 10 mm em média para o mês de setembro, mês mais seco para toda região da sub-bacia do rio Taperoá e Alto Paraíba.

Na Figura, 8 tem-se o IAC da sub-bacia do Alto Paraíba, na qual ocorre alternância de anos secos e úmidos, com maior quantidade de anos secos, até o início da década de 50, como visto na sub-bacia do rio Taperoá, após esse período ocorre a modificação no padrão da 
precipitação (ponto de inflexão), com anos secos consecutivos em todo o período até o final da década cotada.

Nos meados da década de 60, esse padrão se modifica, com atuação de anos úmidos consecutivos durante todo o período, diferente da década passada. No início dos anos 80, os valores voltam a sua normalidade com a mesma alternância vista antes da década de 50 , ou seja, a variabilidade climática a qual a sub-bacia do Alto Paraíba estava submetida diminuiu sua influência, voltando a sua normalidade, mas com maior ocorrência de anos úmidos para toda região.

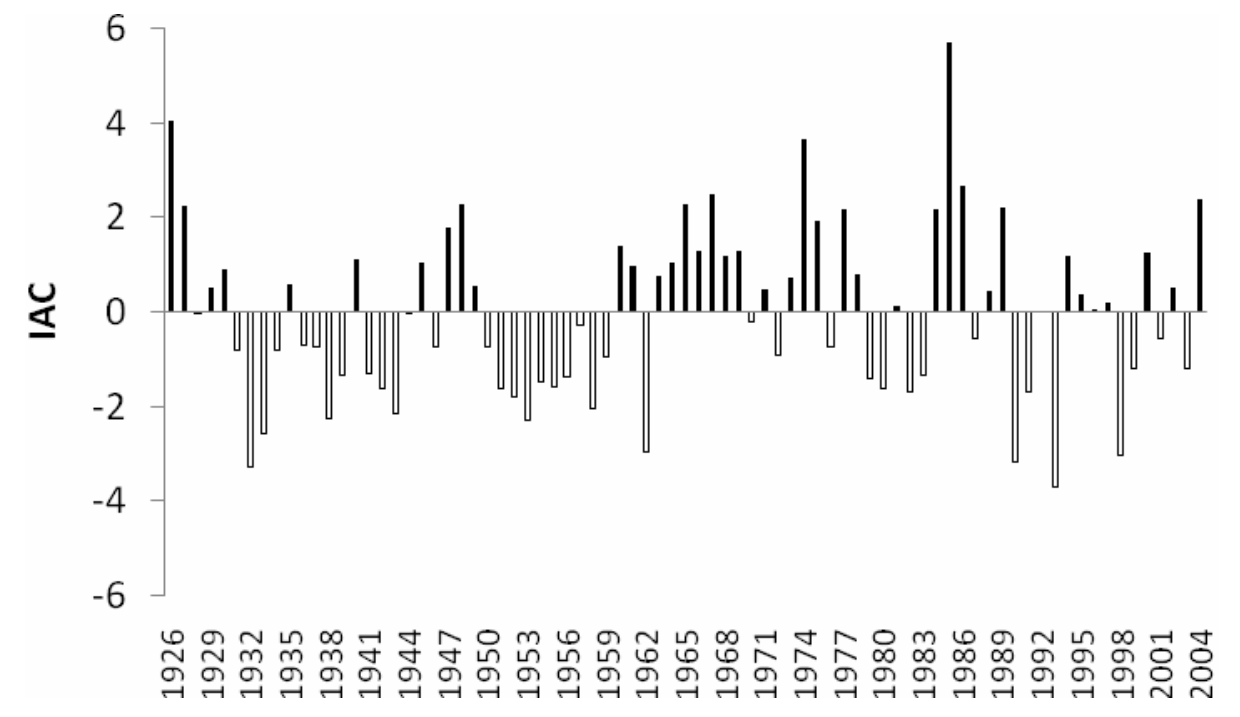

Figura 8. IAC da sub-bacia do Alto Paraíba.

A Figura 9 mostra a variabilidade dos anos secos de 1987 e 1990 para a sub-bacia do Alto Paraíba, os quais apresentaram IAC negativos para todos os meses, com exceção do mês de março de 1987, o qual foi positivo, ou seja, um mês chuvoso dentro de um ano seco.

A precipitação total da quadra chuvosa desses anos foi de $284 \mathrm{~mm}$ em 1987 e de 52,4 mm em 1990, equivalendo a 72,8\% e 40,3\% do total anual, respectivamente.

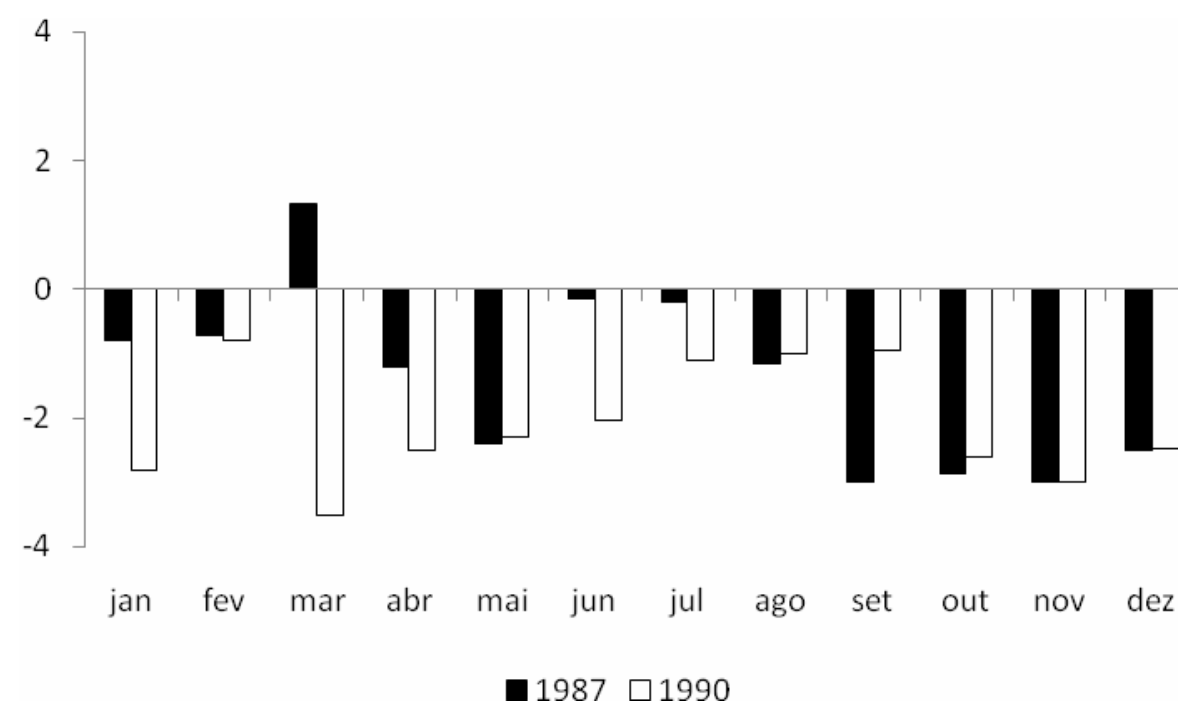

Figura 9. IAC mensais de anos secos da sub-bacia do Alto Paraíba.

Outro ponto importante é que a quadra mais seca iniciou-se com uma variação em 1987, nos seus primeiro dois meses, com valores positivos de IAC, logo após valores negativos, e para 2004 o padrão seguiu a normalidade, de uma quadra seca com todos os meses com 
valores negativos de IAC. Dessa forma, a quadra chuvosa contribuiu com 514,5 mm para o ano de 1984 e 178,9 mm para o ano de 2004, o que equivale a 74,9\% do total anual do primeiro ano e $25,2 \%$ do total anual, respectivamente.

O IAC mensal dos anos úmidos de 1984 e 2004 (Figura 10) da sub-bacia do Alto Paraíba apresenta-se positivo na quadra chuvosa, em sua maioria nos meses do ano de 1984 e negativos para os meses da quadra chuvosa do ano de 2004. Evidencia-se que a atuação da La Niña, como foi citado anteriormente, influenciou todo ano de 1987 e que os sistemas que geraram intensa precipitação no ano de 2004 na região ocorreram apenas no inicio do ano, como citado por Brito e Braga (2005), favorecendo uma quadra chuvosa abaixo da média histórica da sub-bacia do alto Paraíba, mas com valores superiores nos meses de janeiro e fevereiro do mesmo ano.

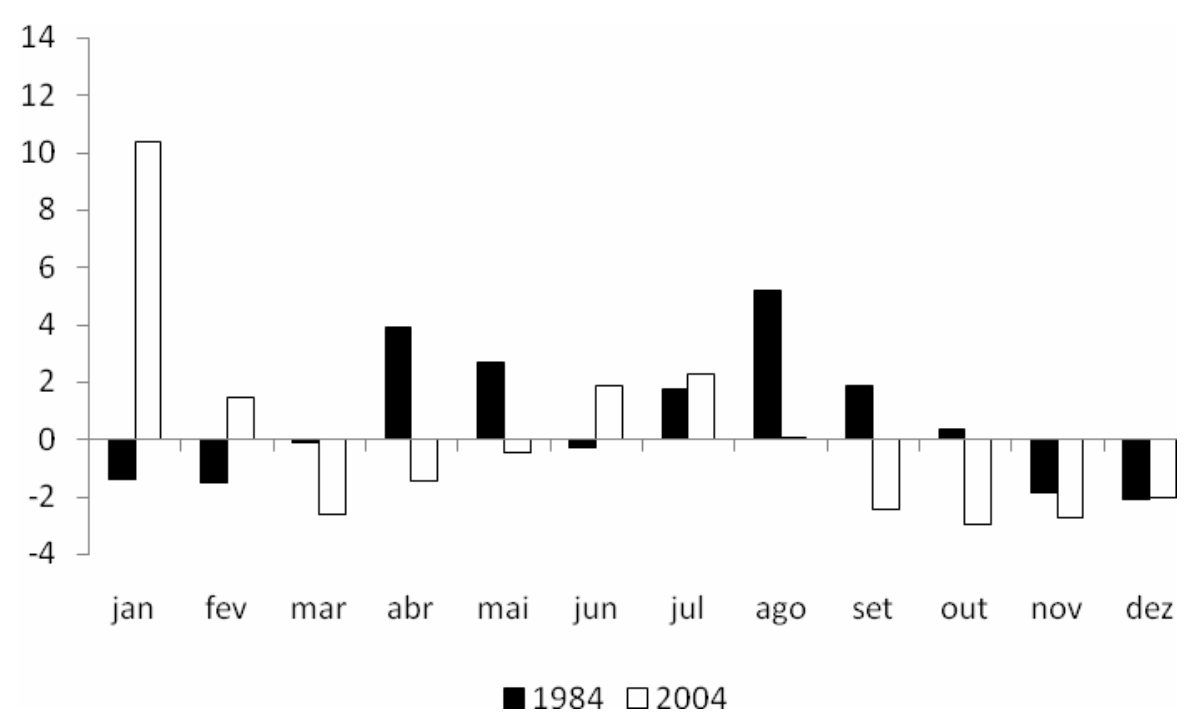

Figura 10. IAC mensais de anos úmidos da sub-bacia do Alto Paraíba.

A Figura 11 mostra a espacialização temporal da precipitação da sub-bacia do Médio Paraíba, com média aproximada de $50 \mathrm{~mm}$ e período chuvoso nos meses de abril a julho, diferentemente das sub-bacias citadas anteriormente, que tem seu período chuvoso de fevereiro a maio. A quadra chuvosa da região é bem definida em todos os meses que a compõem, todos os seus valores apresentam-se acima de $80 \mathrm{~mm}$ em média e menores valores de precipitação ocorrem nos meses de setembro a dezembro como as demais sub-bacias, com valores mínimos em torno de $10 \mathrm{~mm}$ em média.

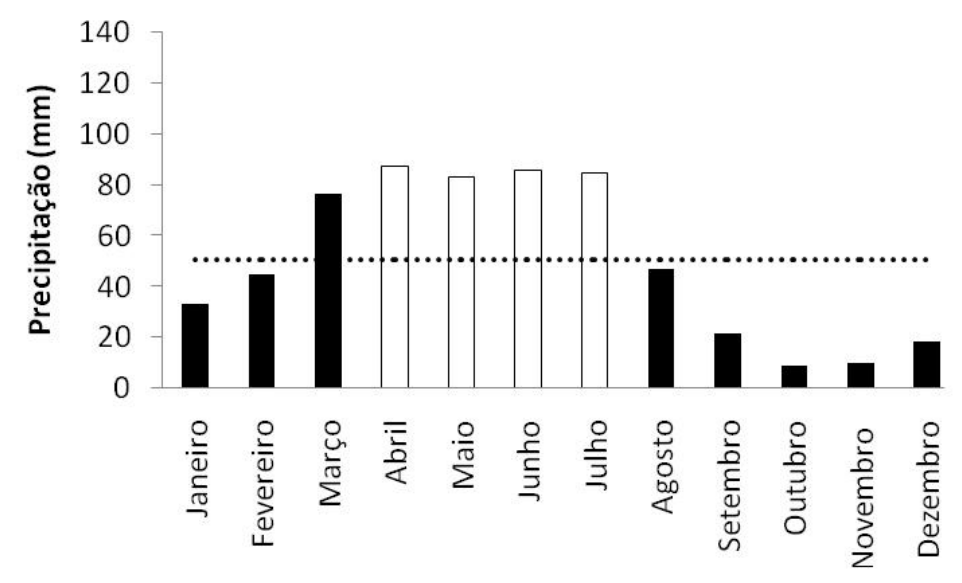

Figura 11. Fluviograma da sub-bacia do Médio Paraíba. 
O IAC da sub-bacia do Médio Paraíba (Figura 12) apresenta a mesma variação de anos secos e úmidos até o inicio da década de 50, como visto para as sub-bacias do rio Taperoá e alto Paraíba. Essa semelhança também ocorre com o surgimento do "ponto de inflexão" na década de 50, o qual modifica o padrão da precipitação e mostra que o período foi demasiadamente seco para a sub-bacia do Médio Paraíba.

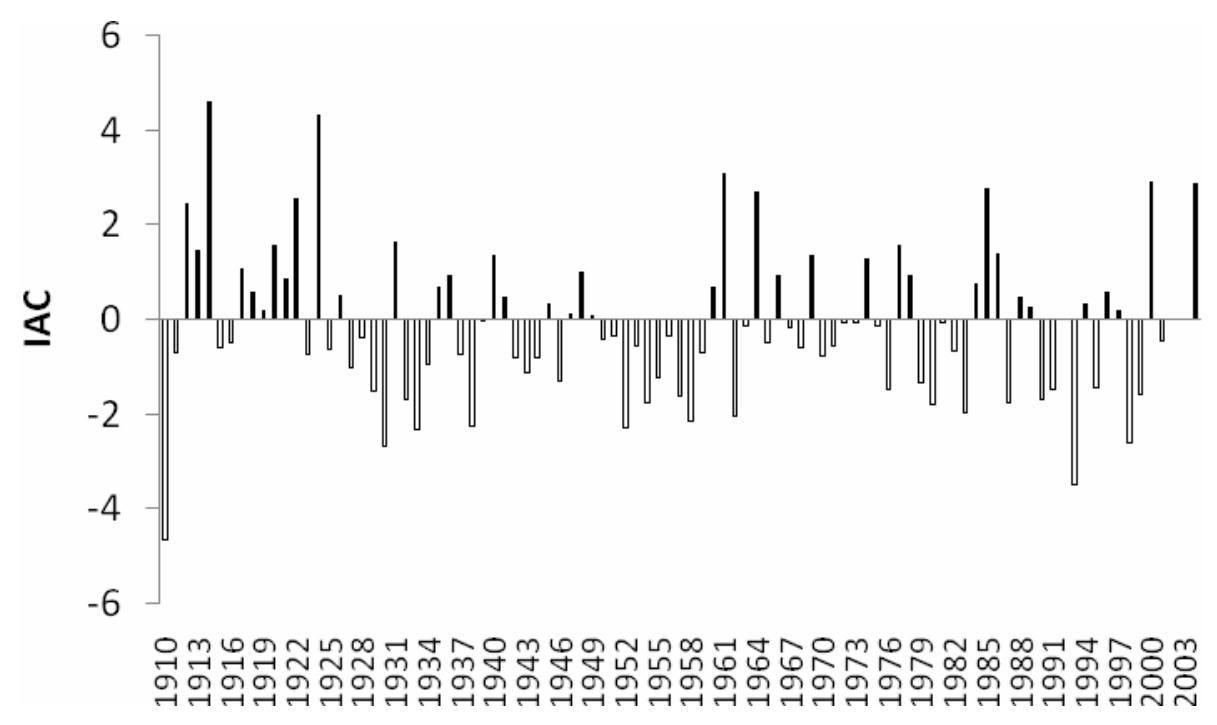

Figura 12. IAC sub-bacia do Médio Paraíba.

O diferencial da sub-bacia do Médio Paraíba para as demais já citadas é que, logo após a modificação do padrão da precipitação na década de 50, o padrão volta a normalidade, com alternância de anos secos e úmidos como visto anteriormente da modificação do padrão, diferentemente das outras sub-bacias, que após esse período são assoladas por períodos úmidos e depois o padrão é restabelecido.

Os anos secos de 1987 e 1990 para a sub-bacia do Média Paraíba (Figura 13) mostram IAC negativos na maioria dos meses dos anos, exceto nos meses de março e abril de 1987, que, dentro da estação chuvosa de um ano seco, obtiveram valores positivos de IAC, e também junho, julho e agosto de 1990.

A quadra chuvosa teve totais pluviométricos de precipitação de 291,6 mm em 1987 e de $226,5 \mathrm{~mm}$ em 1990, equivalendo a $70,8 \%$ e $54,2 \%$ do total anual, respectivamente.

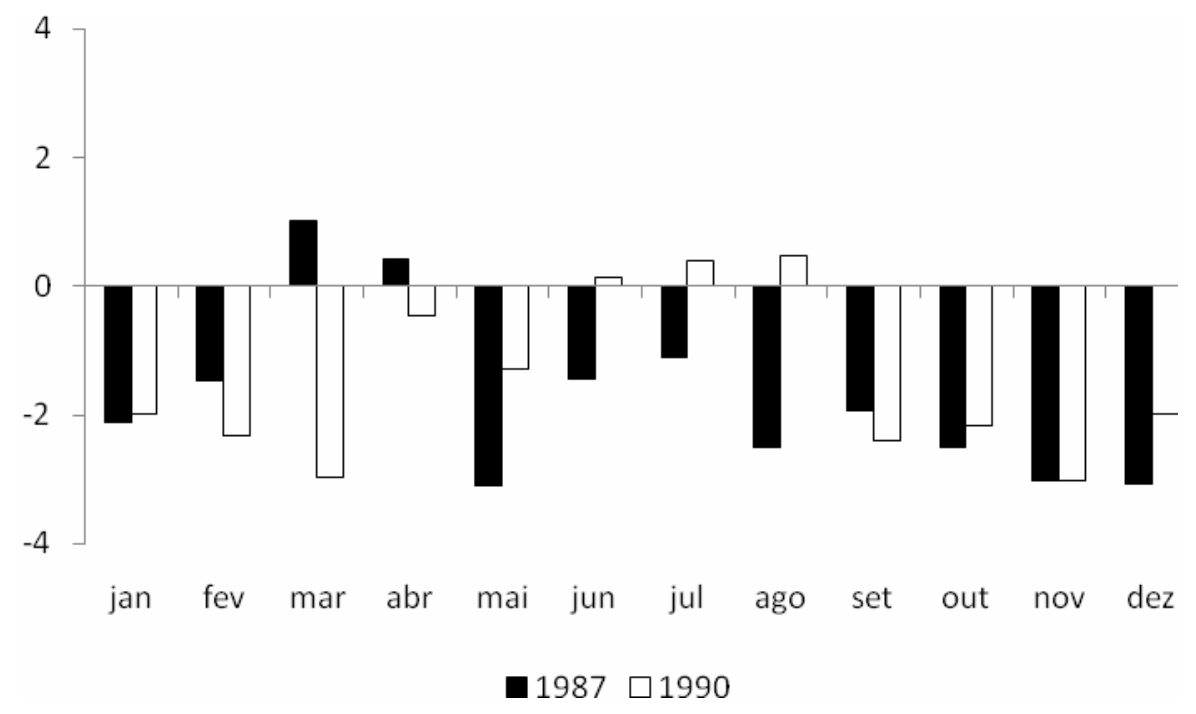

Figura 13. IAC mensais de anos secos da sub-bacia do Médio Paraíba. 
Para os anos úmidos de 1984 e 2004 da sub-bacia do Médio Paraíba (Figura 14), observam-se valores positivos na quadra chuvosa nos meses de abril e maio de 1984 e maio e junho de 2004, mas deve-se salientar que essa região obteve períodos mais úmidos do que as demais regiões adentro do continente, o qual gera maior precipitação na sub-bacia do médio Paraíba, precipitação esta advinda dos Distúrbios de Leste (DL) atuantes nessa época, principalmente no ano de 2004 que, de acordo com Brito e Braga (2005) foram um dos sistemas responsáveis pela precipitação e, para os demais meses, sistemas como Vórtices Ciclônicos de Ar Superior (VCAS) e Zona de Convergência Intertropical (ZCIT) no período, e em 1984 por causa da atuação da La Niña.

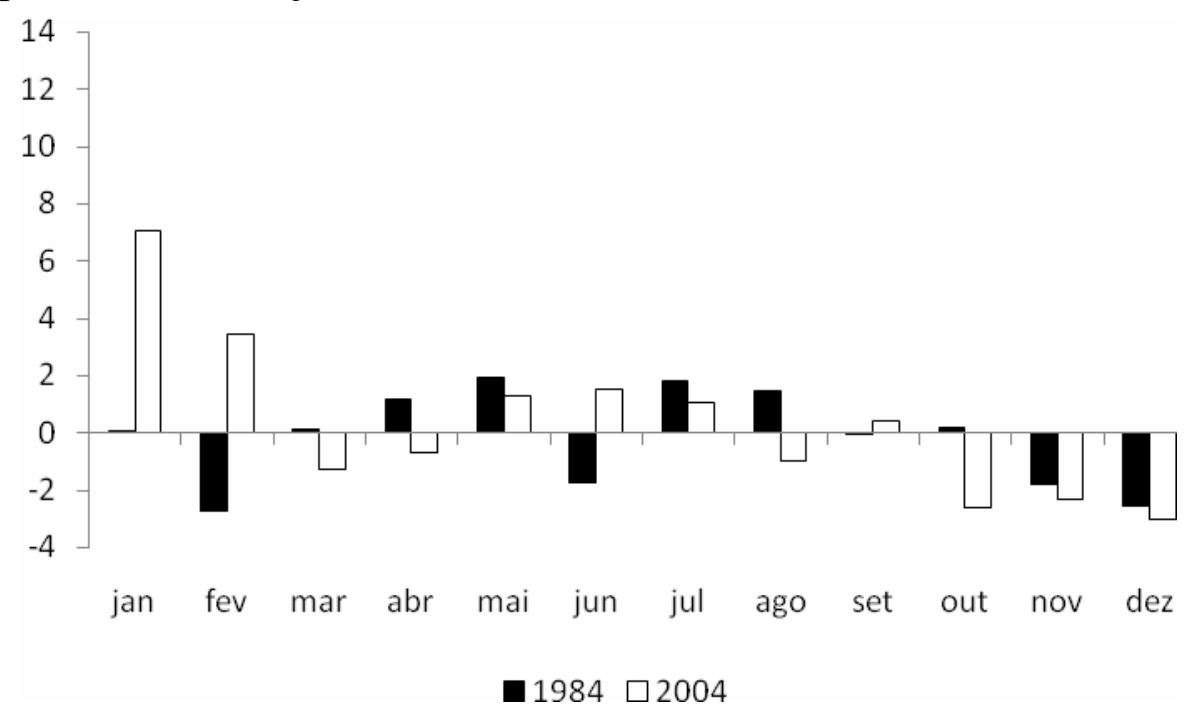

Figura 14. IAC mensais de anos úmidos da sub-bacia do Médio Paraíba.

A quadra mais seca da sub-bacia do Médio Paraíba foi mais amena do que as demais, com valores negativos de IAC bem inferiores aos vistos anteriormente. Com contribuição da quadra chuvosa de 411,8 mm para o ano de 1984 e 377,9 mm para o ano de 2004, equivalendo a $58 \%$ e $37,2 \%$ do total anual, respectivamente.

Por fim, ao análisar-se a climatologia temporal da sub-bacia do Baixo Paraíba (Figura 15), a qual aborda não uma quadra chuvosa e, sim, cinco meses chuvosos, de março a julho, semelhante a sub-bacia do Médio Paraíba, verifica-se que o padrão climático de precipitação das duas sub-bacia são idênticos, o qual sugere que os sistemas atuantes na região são os mesmos.

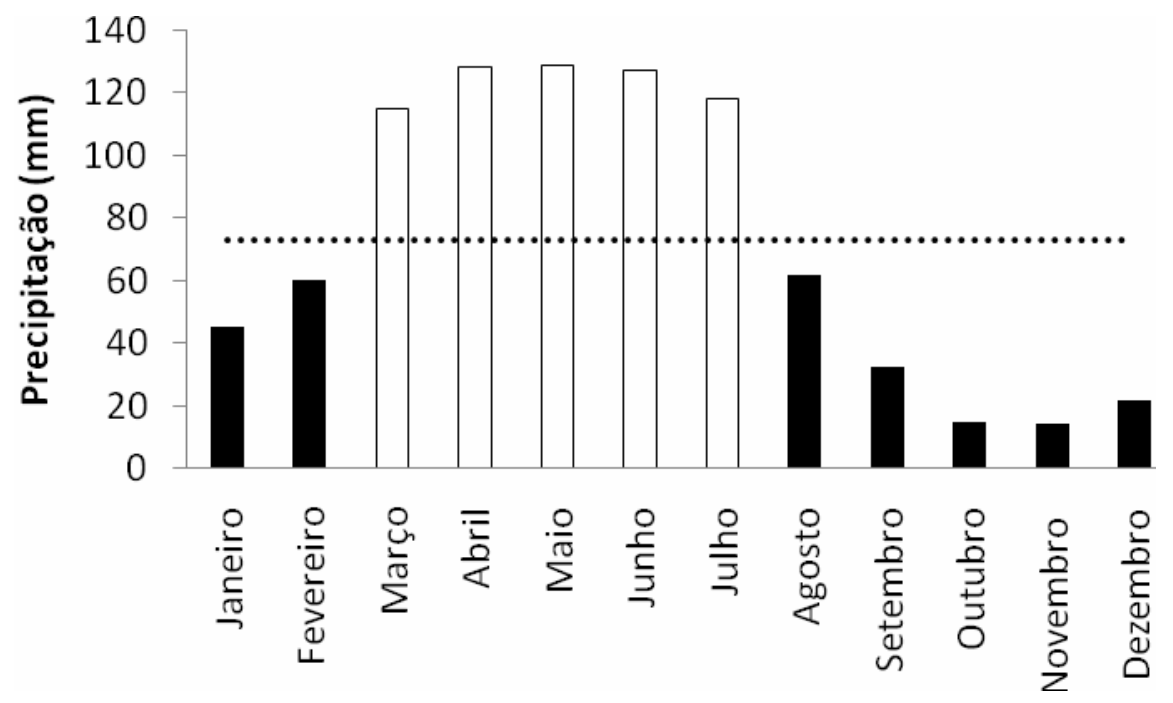

Figura 15. Fluviograma da sub-bacia do Baixo Paraíba. 
A sub-bacia do Baixo Paraíba tem média de 70 mm mensal com valores máximos em toda estação chuvosa de $118 \mathrm{~mm}$, o qual demonstra que a influência do contraste térmico entre o continente e oceanos e demais sistemas atuantes na região tem sua influência nesse valor, e a quadra mais seca da região se estende de setembro a dezembro, com o mês mais significativo, outubro, com valor de $20 \mathrm{~mm}$.

O IAC da sub-bacia do Baixo Paraíba (Figura 16) é o mais variados dos outros resultados, o “ponto de inflexão” não é bem definido nessa região, mostrando que a variabilidade temporal climática é bem mais intensa do que as demais sub-bacias. O motivo deve estar ligado à proximidade do continente ao oceano e a pouca diferença entre as estações de ano.

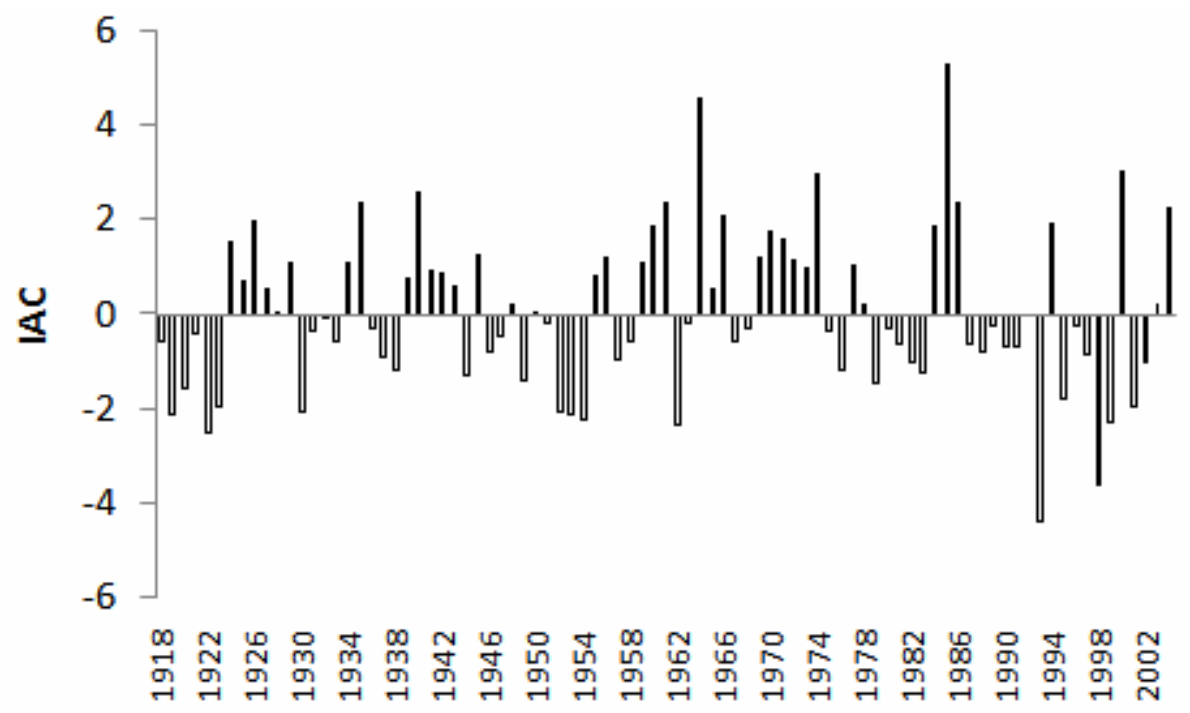

Figura 16. IAC sub-bacia do Baixo Paraíba.

Os anos secos de 1987 e 1990 da sub-bacia do Baixo Paraíba (Figura 17), exibem uma grande variabilidade temporal, diferentemente das demais sub-bacias, nas quais esses mesmos meses dos anos secos se comportaram de forma não tão variada como visto nessa sub-bacia. Mostra que a variabilidade a qual uma região próxima ao litoral sofre com os efeitos do relevo não acidentado, contraste terra e oceano e alta umidade são primordiais para esse padrão tão distinto das demais sub-bacias hidrográficas.

Sua quadra chuvosa teve totais pluviométricos de precipitação de 516,6 mm em 1987 e de 379,9 mm em 1990 , equivalendo a $66 \%$ e $48,8 \%$ do total anual, respectivamente.

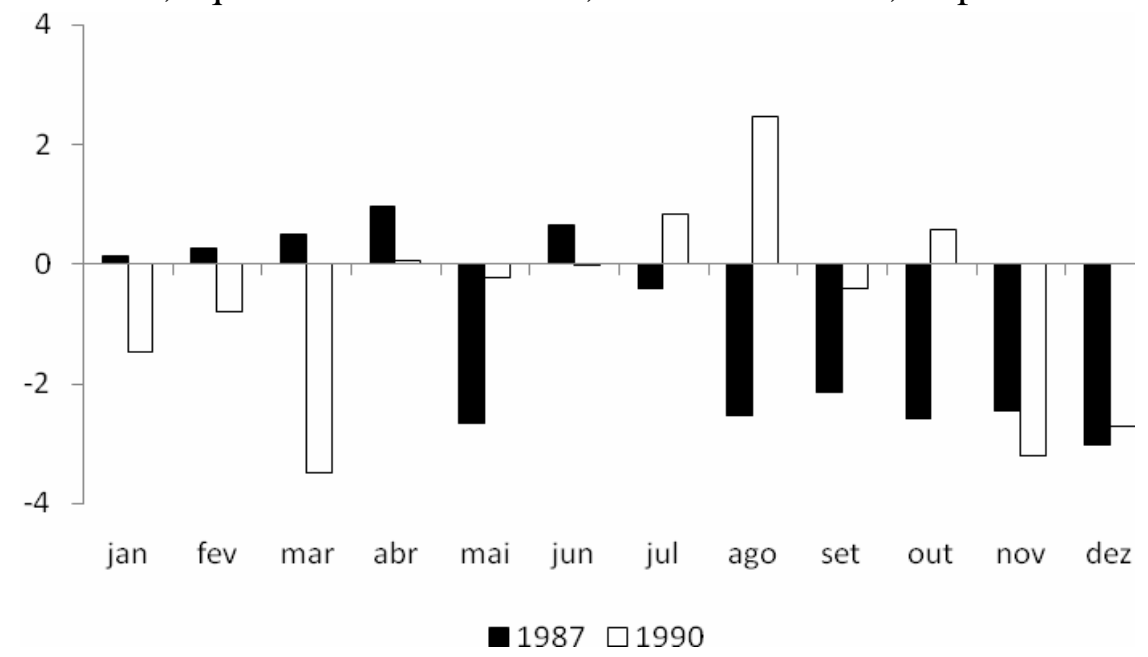

Figura 17. IAC mensais de anos secos da sub-bacia do Baixo Paraíba. 
De forma similar, os anos úmidos de 1984, com quadra chuvosa de 641,1 mm, correspondendo a 56,4\% e 2004 com 471,2, que equivale a 39,5\% da sub-bacia do Baixo Paraíba (Figura 18), têm-se a mesma variabilidade temporal climática, sem padrão definido. Com valores positivos de IAC dentro da estação chuvosa de ambos os anos e negativos no final do ano, o qual deveria ser positivo por causa das chuvas de verão que atuam na região.

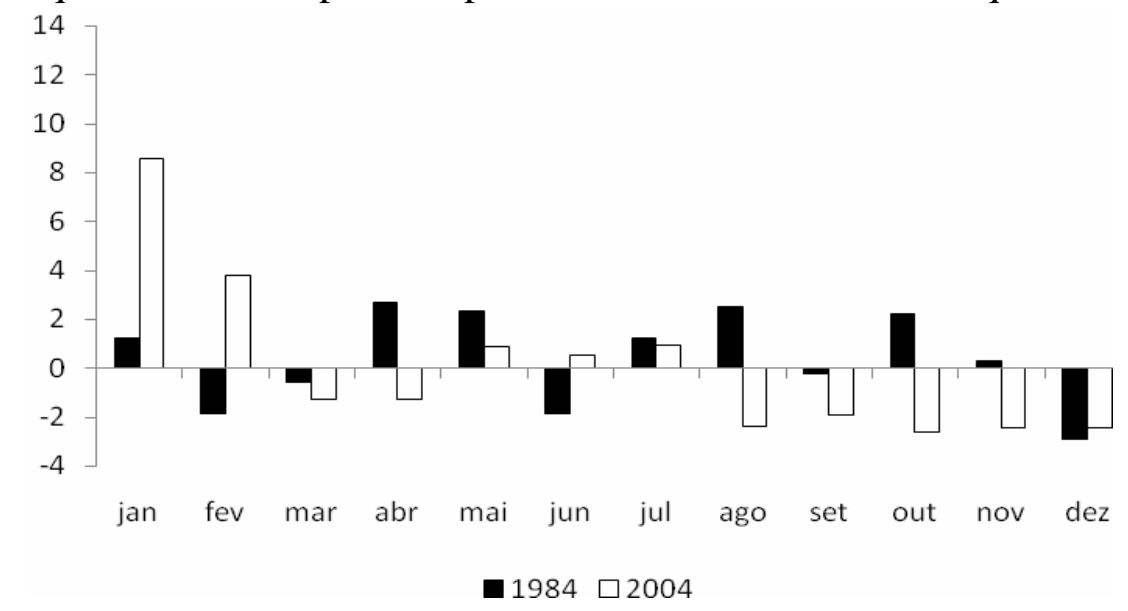

Figura 18. IAC mensais de anos úmidos da sub-bacia do Baixo Paraíba.

Para analisar a variabilidade espaço-temporal da precipitação na bacia do rio Paraíba construíram-se gráficos e figuras para melhor ilustrar as peculiaridades do clima em toda região de estudo. Dessa forma, dividiu-se o ano em quadrimestres, o primeiro indo de janeiro a abril (Quadra 1), com inicio do quadrimestre com um mês seco, passando a chuvoso até o segundo quadrimestre, que abrange os meses de maio a agosto (Quadra 2), que tem sua transição diferente do quadrimestre anterior, de meses chuvosos a secos; e o terceiro, mais seco, de setembro a dezembro (Quadra 3), período crítico para toda a bacia do rio Paraíba.

Tendo em vista toda essa variabilidade, a climatologia temporal da precipitação da bacia do rio Paraíba (Figura 19) concentra metade dos meses do ano acima da média e a outra metade abaixo, com meses mais úmidos e mais propícios a precipitação, os meses de fevereiro, março, abril, maio, junho e julho, (Quadra 1 e 2), com ênfase para o mês de março, que mostra valor acima de $100 \mathrm{~mm}$ em média para toda região de estudo.

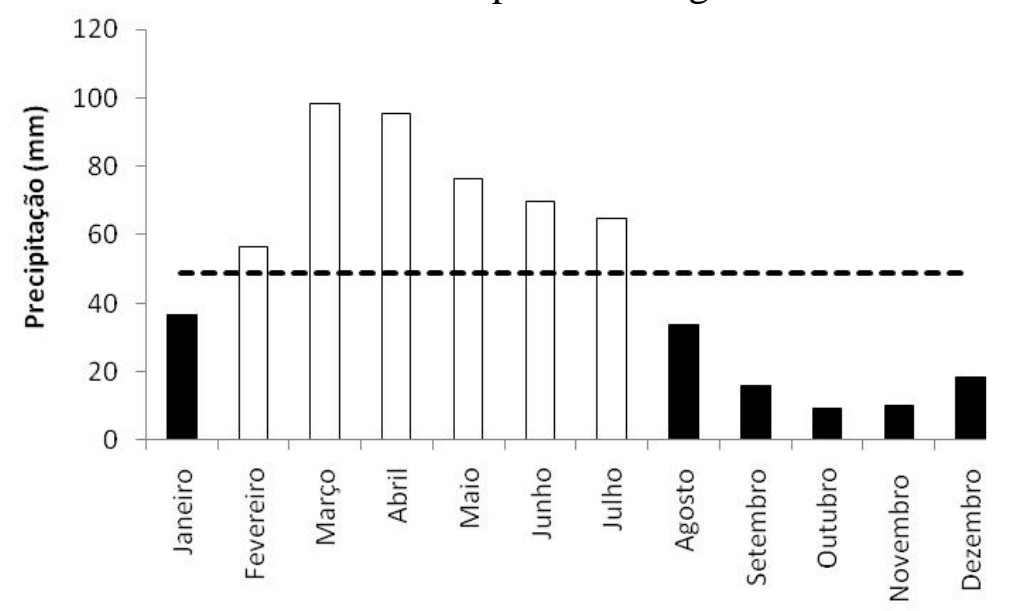

Figura 19. Variação temporal média da precipitação da bacia do rio Paraíba.

Com os valores de IAC anual de 1987 e 1990 (anos secos) e 1984 e 2004 (anos chuvosos) foram espacializados e classificados de acordo com a Tabela 1.

Dessa forma, observa-se na Figura 20, o ano seco de 1987, o qual obteve maior quantidade de IAC negativos para toda região da bacia hidrográfica do rio Paraíba, com exceção no oeste de região da sub-bacia do rio Taperoá e norte do baixo Paraíba. Tem-se 
ARAÚJO, L. E.; MORAES NETO, J. M.; SOUSA, F. A. S. Classificação da precipitação anual e da quadra chuvosa da bacia do rio Paraíba utilizando índice de Anomalia de Chuva (IAC). Ambi-Agua, Taubaté, v. 4, n. 3, p. 93-110, 2009. (doi:10.4136/ambi-agua.105)

como principal sistema de grande escala causador dessa variabilidade negativa o intenso El Niño ocorrido nesse ano, como sugerido por Da Silva (2009).

A classificação do ano como seco foi evidente em toda região da bacia, com outras classificações de úmidos, no oeste da região da sub-bacia do rio Taperoá e norte do Baixo Paraíba, e com classificação de muito seco no sudeste da sub-bacia do Alto Paraíba e leste da sub-bacia do Baixo Paraíba. Evidencia-se que por essa classificação o ano de 1987 foi seco em quase sua totalidade na bacia hidrográfica do rio Paraíba.

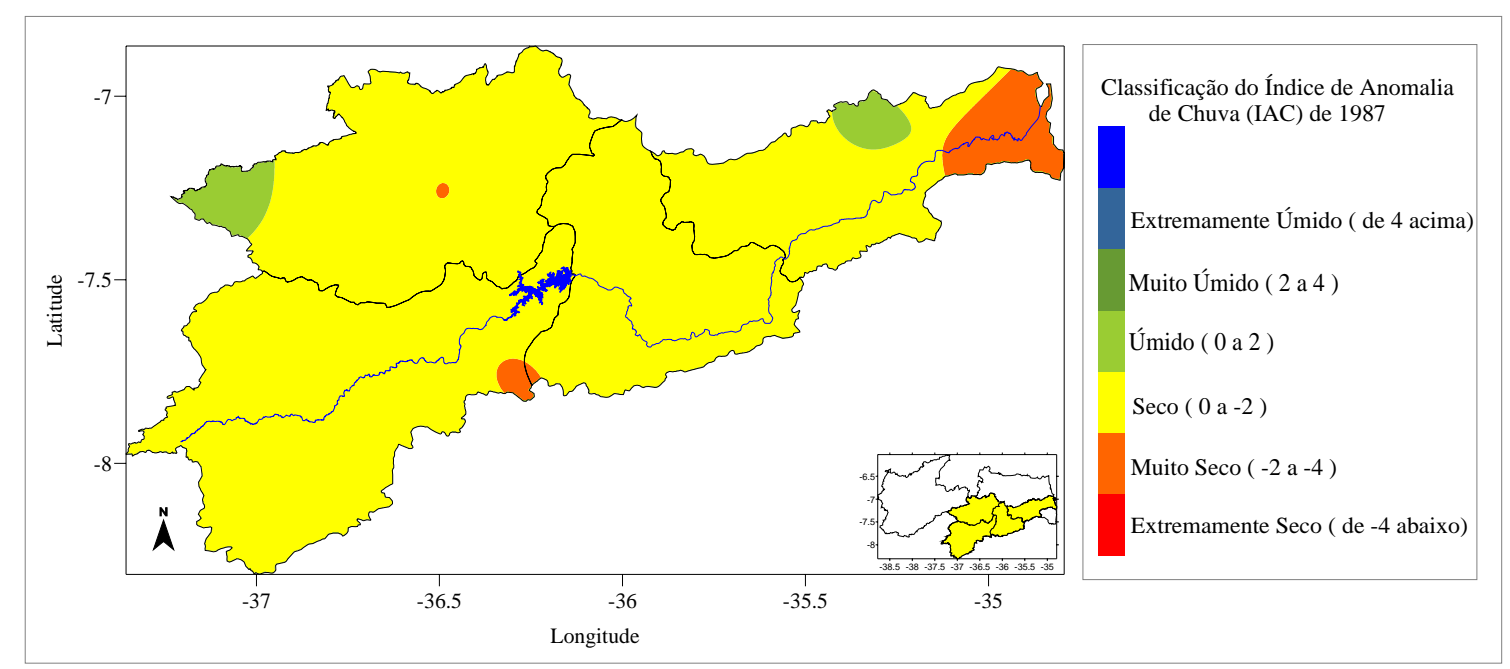

Figura 20. Classificação do índice de Anomalia de Chuva da bacia hidrográfica do rio Paraíba para o ano de 1987.

A Figura 21 mostra o ano de 1990 que, similarmente ao ano de 1987, foi seco, mas com maior intensidade em suas classificações espaciais do IAC. A região da sub-bacia do rio Taperoá quase que totalmente classifica-se em muito seco, com uma pequena região com classe extremamente seco a Sudoeste e seco ao sul da bacia. Para a sub-bacia do Alto Paraíba a classificação é de muito seco para grande parte, e demais classificação em extremamente seco a oeste e seco a nordeste. Já para o Médio Paraíba ocorreu a variação entre muito seco a oeste e seco a leste e, por fim, o Baixo Paraíba que obteve um setor a oeste da sub-bacia como úmido, seguindo por seco até chegar ao litoral que se classifica como muito seco.

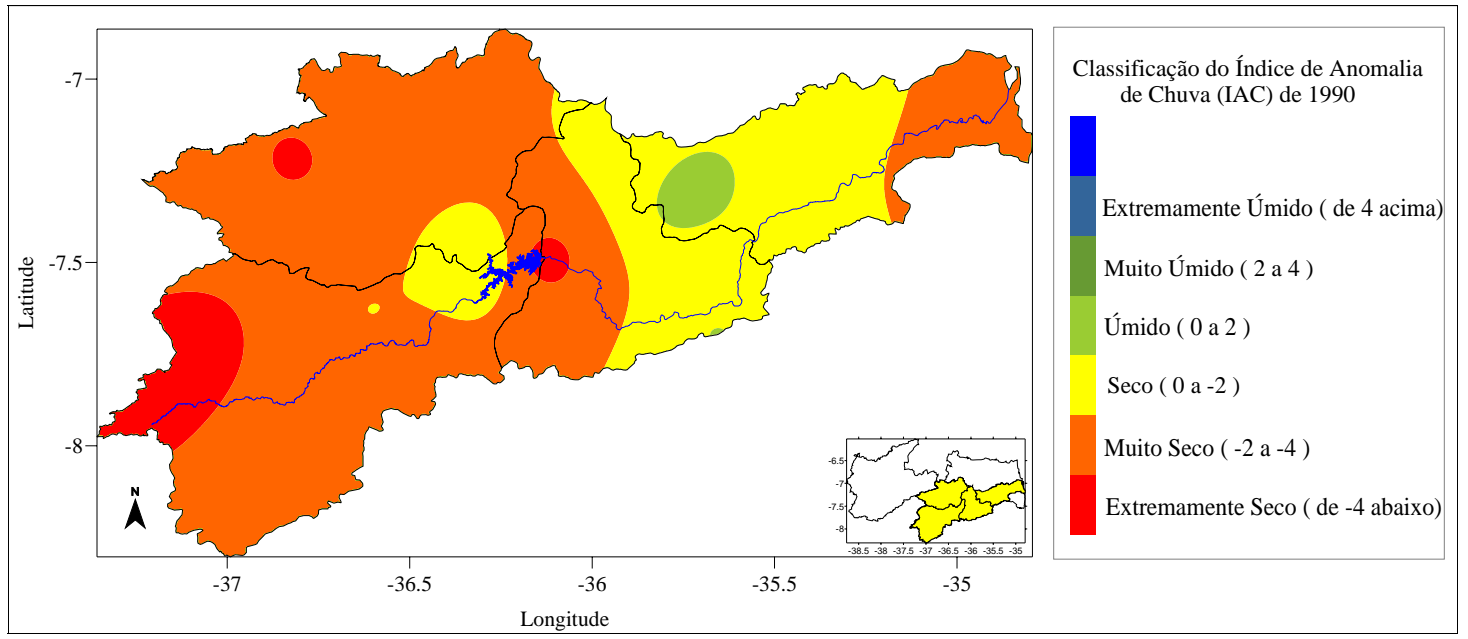

Figura 21. Classificação do índice de Anomalia de Chuva da bacia hidrográfica do rio Paraíba para o ano de 1990. 
Evidencia-se dessa forma que, o ano de 1990 foi um ano muito seco, por causa da atuação de um El Niño muito forte que teve inicio entre os anos de 1990 e 1993 (INPE, 2000), causando pouca precipitação na região de estudo.

Como um dos representantes de ano úmido, o ano de 1984 (Figura 22) mostra que foi um ano úmido em toda região da bacia hidrográfica do rio Paraíba, com exceção no sudoeste da região da sub-bacia do rio Paraíba, centro-norte da sub-bacia do Alto Paraíba e com classificação de muito úmido no oeste desta. Esses valores positivos de IAC são oriundos da precipitação favorecida pela atuação neste ano de uma La Niña não tão intensa na região.

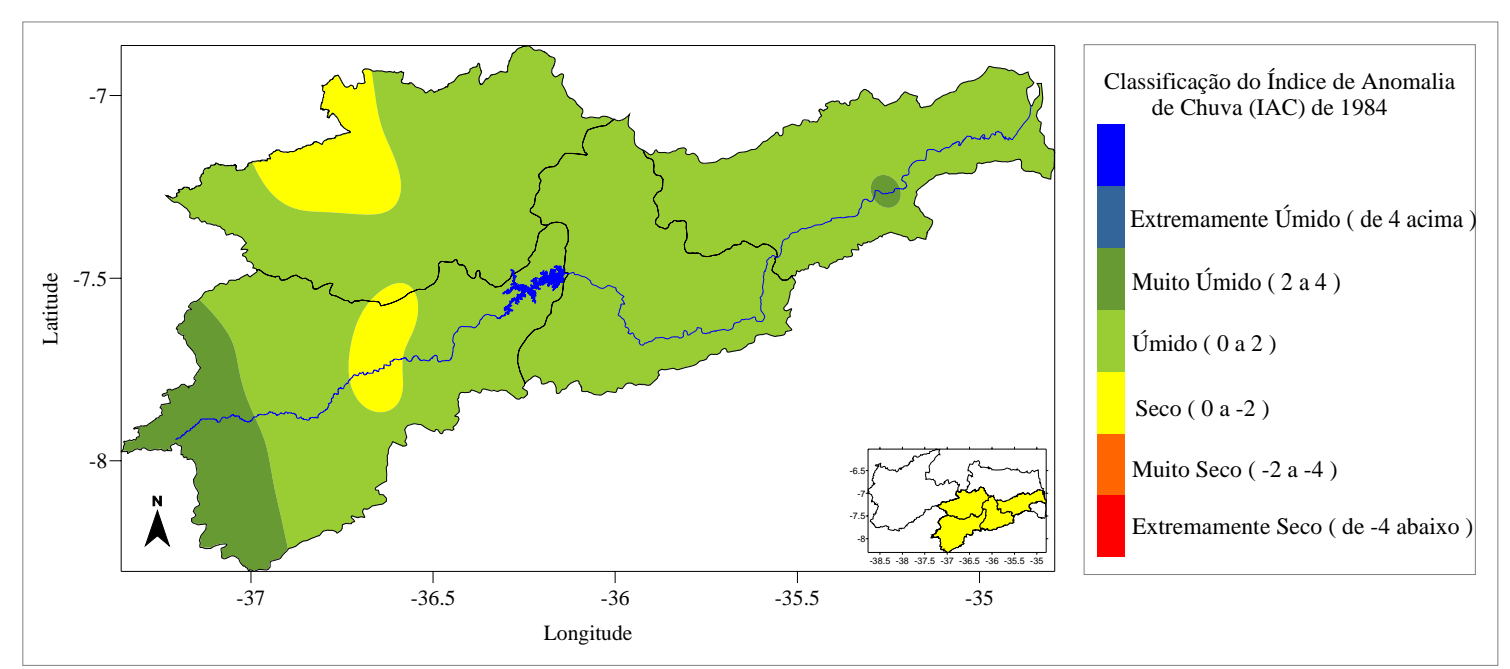

Figura 22. Classificação do índice de Anomalia de Chuva da bacia hidrográfica do rio Paraíba para o ano de 1984.

Por fim, 2004 (Figura 23), mostra-se como ano intensamente úmido na bacia hidrográfica do rio Paraíba, mas vale ressaltar que, de acordo com o IAC mensal do mesmo ano para a região, sua intensidade foi mais evidente nos meses de janeiro e fevereiro (Figuras 6, 10, 14 e 18) por causa da atuação da Zona de Convergência Intertropical (ZCIT) e dos Vórtices Ciclônicos de Altos Níveis (VCAN).

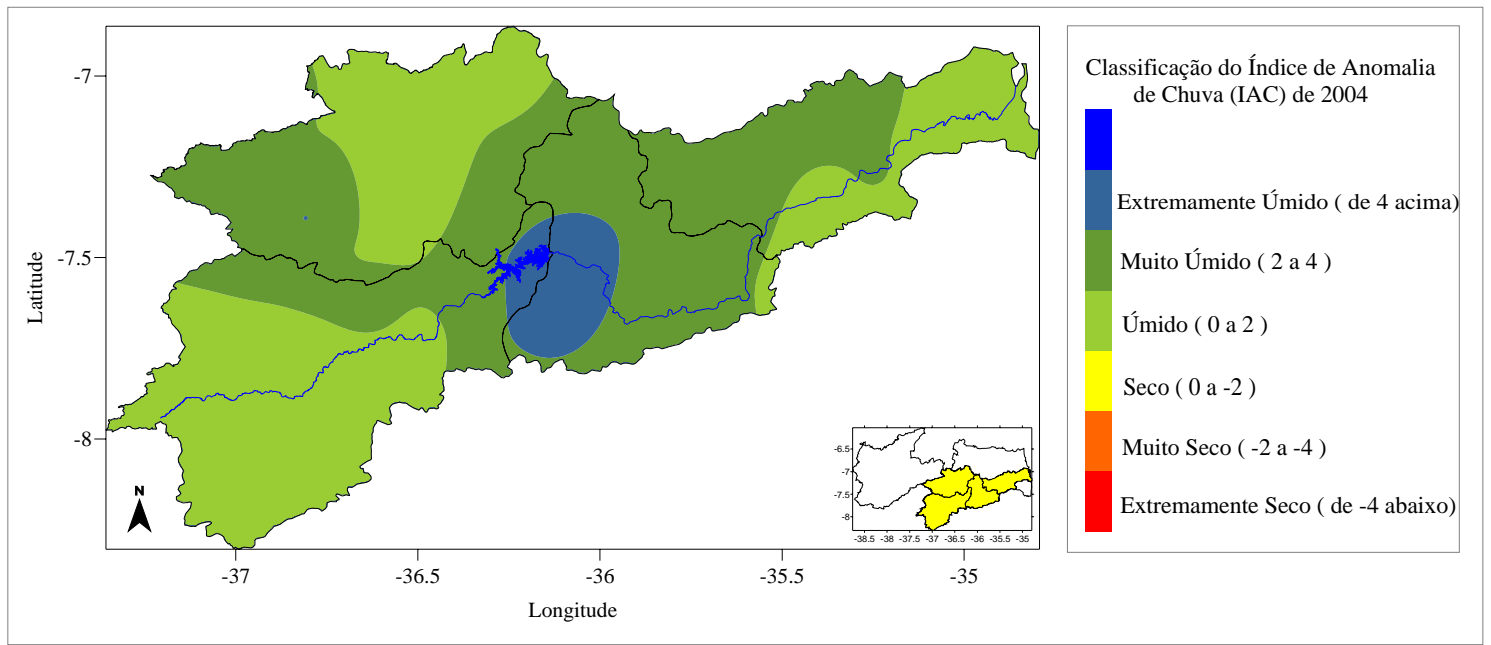

Figura 23. Classificação do índice de Anomalia de Chuva da bacia hidrográfica do rio Paraíba para o ano de 2004.

Nesse ano, a classificação do IAC foi de chuvoso no centro norte da região da sub-bacia do rio Taperoá, centro sudoeste da sub-bacia do Alto Paraíba e leste da sub-bacia do Baixo Paraíba. De muito úmido a oeste da região da sub-bacia do rio Taperoá, norte e leste da subbacia do Alto Paraíba, quase toda sub-bacia do Médio Paraíba e parte do sudoeste da sub- 
ARAÚJO, L. E.; MORAES NETO, J. M.; SOUSA, F. A. S. Classificação da precipitação anual e da quadra chuvosa da bacia do rio Paraíba utilizando índice de Anomalia de Chuva (IAC). Ambi-Agua, Taubaté, v. 4, n. 3, p. 93-110, 2009. (doi:10.4136/ambi-agua.105)

bacia do Baixo Paraíba, e extremamente úmido no centro da bacia hidrográfica do rio Paraíba, região na qual se localiza o açude Epitácio Pessoa, que foi favorecido por um bom aporte hídrico nos dois primeiros meses desse ano. Desta forma, o ano de 2004 classifica-se com um ano muito úmido.

\section{CONCLUSÕES}

A bacia do rio Paraíba apresenta semelhança entre o padrão de precipitação da região do Taperoá e Alto Paraíba, em relação à quantidade de anos secos e úmidos, em destaque os anos de 1962, 1990, 1993 e 1998 (secos), e 1974, 1985 e 2004 (úmidos) e das sub-bacias do Médio e Baixo Paraíba, com destaque para os anos de 1910, 1930, 1952, 1993 e 1998 (secos) e 1914, 1924, 1961, 1985, 2000 e 2004 (úmidos).

Na região do Taperoá e Alto Paraíba, foi encontrado um "ponto de inflexão" na distribuição de precipitação. Até a década de 1960, foram observados anos secos consecutivos; no entanto após esses anos, houve uma diminuição na frequência de anos secos e aumento da severidade dos eventos. Para as sub-bacias do Médio e Baixo Paraíba, foi verificada semelhança na alternância entre anos secos e úmidos ao longo da série de IAC.

Em comum para toda a bacia do rio Paraíba, foi encontrado um período seco entre as décadas de 1950 e 1960. No entanto, para o Baixo Paraíba foi observado menor intensidade.

A variação temporal do IAC dos anos secos de 1987 e 1990 mostrou que esses anos têm uma distribuição mais correta em relação ao padrão da precipitação vista na climatologia da região, principalmente dentro da estação chuvosa do ano. Em relação aos anos úmidos de 1984 e 2004, a distribuição do IAC é bem irregular, principalmente dentro da estação chuvosa.

A variação espacial do IAC dos anos secos de 1987 e 1990 mostrou a variação espacial do índice para toda região indo de seco a extremamente seco, principalmente no ano de 1990, devido à atuação de um El Niño muito forte. E nos anos úmidos de 1984 e 2004, observou-se que o ano de 2004 foi responsável por maior representação do índice em toda bacia, principalmente no início do ano, passando de regiões úmidas a extremamente úmidas.

Neste trabalho foi verificado que o IAC pode ser utilizado como uma ferramenta para o acompanhamento climático de uma localidade, nesse caso uma bacia hidrográfica, além de ser utilizado para regionalização, podendo também, por meio desse monitoramento gerar prognósticos e diagnósticos da climatologia local.

\section{REFERÊNCIAS}

ARAÚJO, L. E. Análise estatística de chuvas intensas na bacia hidrográfica do rio Paraíba. 2006. 94f. Dissertação (Mestrado em Meteorologia) - Universidade Federal de Campina Grande, Campina Grande, 2006.

ARAÚJO, L. E.; BECKER, C. T.; PONTES, A. L. Periodicidade da precipitação pluviométrica no estado da Paraíba. In: CONGRESSO BRASILEIRO DE AGROMETEOROLOGIA, 13., 2003, Santa Maria. Anais... Santa Maria: UNIFRA, 2003.

BRITO, J. I. B.; BRAGA, C. C. Chuvas no Estado da Paraíba em 2004. Boletim da Sociedade Brasileira de Meteorologia, v. 28, p. 27-32, 2005.

INSTITUTO NACIONAL DE PESQUISAS ESPACIAIS - CPTEC/INPE. El Niño. Boletim Informativo do Instituto Nacional de Pesquisas Especiais, 2000. Disponível em: <http://www.cptec.inpe.br/enos/globo_elnino.shtml>. Acesso: 12 set. 2000. 
DA SILVA, D. F. Análise de aspectos climatológicos, agroeconômicos, ambientais e de seus efeitos sobre a bacia hidrográfica do rio Mundaú (AL e PE). 2009. Tese (Doutorado em Recursos Naturais) - Universidade Federal de Campina Grande, Campina Grande, 2009.

DA SILVA, D. F.; ARAÚJO, L. E.; KAYANO, M. T.; SOUSA, F. de A. S. Avaliação dos impactos da variabilidade climática na distribuição pluviométrica da Bacia do Rio Mundaú através do IAC. In: SIMPÓSIO BRASILEIRO DE DESASTRES NATURAIS E TECNOLÓGICOS, 2., 2007, Santos. Anais... Santos: [S.n.], 2007. v. 72.

ESPINOZA, E. S. Distúrbios nos ventos de leste no Atlântico tropical. 1996. $127 f$. Dissertação (Mestrado em Meteorologia) - Instituto Nacional de Pesquisas Espaciais, São José dos Campos, 1996.

FREITAS, M. A. S. A Previsão de secas e a gestão hidroenergética: o caso da Bacia do Rio Parnaíba no nordeste do Brasil. In: SEMINÁRIO INTERNACIONAL SOBRE REPRESAS Y OPERACIÓN DE EMBALSES, 2004, Puerto Iguazú. Anais... Puerto Iguazú: CACIER, 2004. v. 1. p. 1-1.

FREITAS, M. A. S. Um sistema de suporte à decisão para o monitoramento de secas meteorológicas em regiões semi-áridas. Revista Tecnologia, Fortaleza, v. suplem., p. 84-95, 2005.

GONÇALVES, W. A.; CORREIA, M. F.; ARAÚJO, L. E.; DA SILVA, D. F.; ARAÚJO, H. A. Vulnerabilidade climática do nordeste Brasileiro: uma análise de eventos extremos na Zona Semi-árida da bacia hidrográfica do São Francisco. In: CONGRESSO BRASILEIRO DE METEOROLOGIA, 14., Florianópolis, 2006. Anais... Florianópolis: CALESA/UFSC, 2006.

KOUSKY, V. E. Frontal influences on northeast Brazil. Monthly Weather Review, v. 107, n. 9, p. $1140-1153,1979$.

KOUSKY, V. E.; GAN, M. A. Upper tropospheric cyclones vórtices in the tropical south atlantic. Tellus, v. 33, p. 538-551, 1981.

MAUGET, S. U. M. Índice padronizado de precipitação (SPI). [S.l.]: C. Springer Science, 2005.

ROOY, M. P. VAN. A Rainfall Anomaly Index Independent of Time and Space. Notes, v. 14, p. 43, 1965.

UVO, C. R. B. A zona de convergência intertropical (ZCIT) e sua relação com a precipitação na região norte e nordeste brasileiro. 1989. 88f. Dissertação (Mestrado em Meteorologia) - Instituto Nacional de Pesquisas Espaciais, São José dos Campos, 1989. 